Sri Lanka J. Aquat. Sci. 20 (1) (2015): 35-45

\title{
Diversity and distribution of cetaceans off Mirissa in the southern coast of Sri Lanka II. Relationship with sea surface temperature, salinity and water density
}

\author{
E.P.D.N. Thilakarathne*, P.B.T. Pradeep Kumara and R.M.G.N. \\ Thilakarathna
}

Department of Oceanography and Marine Geology, Faculty of Fisheries and Marine Sciences \& Technology, University of Ruhuna, Matara, Sri Lanka

*Corresponding author (E-mail: epdarshananuwan@yahoo.com)

\begin{abstract}
Lack of proper scientific data on the behaviour of cetaceans is a major constraint in managing whale and dolphin watching activities without affecting cetacean populations in marine waters off Mirissa, where it has become a high income generating tourist activity. Therefore a shipboard surveys were conducted using a special whale watching boat for 43 days from January to April 2012 in an area of about $940 \mathrm{~km}^{2}$ in Mirissa, southern coast of Sri Lanka to identify the environmental parameters that affect the abundance of cetaceans.

During this study, 8 cetacean species including 6 toothed whale species (Physeter macrocephalus, Globicephala melas, Peponocephala electra, Orcinus orca, Tursiops truncates and Stenella longirostris) and two baleen whale species (Balaenoptera musculus and Balaenoptera physalus) were identified.

Results of the study revealed that relationship between species occurrence and the measured water quality parameters (temperature, salinity and density) was significant $(\mathrm{p}<0.05)$. From the identified species blue whale and melon headed whale can tolerate high density $(1.02 \pm 0.0)$ and salinity (blue whale-36.35 \pm 0.75 ; melon headed-35.55 \pm 0.51$)$ range while blue whale $(28.53 \pm 0.89)$, sperm whale $(28.47 \pm 0.93)$ and spinner whale $(28.66 \pm 1.04)$ can tolerate widee temperature range.
\end{abstract}

Keywords: marine mammals, southern Sri Lanka, temperature, salinity, density, whale watching

\section{Introduction}

Marine waters around Sri Lanka ( $6^{\circ}$ to $10^{\circ} \mathrm{N} ; 80^{\circ}$ to $83^{\circ} \mathrm{E}$ ) are well-known for watching of whales, dolphins and porpoises since a very long time (Alling et al. 1991; Vivekanandan and Jeyabaskaran 2012). Research on cetaceans has shown that the their diversity in Sri Lankan waters is extremely high with 21 species of toothed whales and 5 species of baleen whales (Ilangakoon 2002). Because of this 
high diversity and abundance, marine waters of southern coast of Sri Lanka have become a major area to watch and do scientific investigations on whales. There is high demand off Mirissa in the southern coast of Sri Lanka for whale watching industry due to high tourist attraction (Thilakarathne et al. 2014). However, developing tourism activities, fishing activities such as tuna fishing and krill fishing and shipping and transportation activities may have contributed for large number of dead whales found in the southern coastal waters in the recent past (de Vos et al. 2012).

A proper understanding on the behavior of cetaceans in the southern coastal waters and a proper management system are immediately required to conserve those rare creatures within Sri Lankan waters. Knowledge on their home ranges and inhabiting pattern in southern coastal waters will help to protect and conserve them while developing the whale watching industry. In the present paper, an attempt is made to investigate possible influence of sea surface temperature, salinity and density on the occurrence of cetaceans off Mirissa in the southern coast of Sri Lanka.

\section{Materials and Methods}

Waters of the southern sea of Sri Lanka off Mirissa whale watching site were surveyed for 43 days from January to April 2012. The upper deck of the boat allowed an unobstructed $360^{\circ}$ view.



Figure 1. Study area off Mirissa in southern coast of Sri Lanka. 
During the surveys, sighing of cetaceans was conducted with six trained observers with binoculars (15 X 35) at the upper deck of the boat ( $7 \mathrm{~m}$ above) and simultaneously oceanographic measurements such as sea surface temperature, sea surface salinity and sea surface density within $100 \mathrm{~m}$ area of identified sightings were measured using digital thermometer and refractometer. One observer covered $60^{\circ}$ of the total view field and photographs and video clips captured from high resolution digital cameras by the observer were used for species identification and for estimation of the number of individuals in each pod. The accuracy of pod sizes of those less than 100 individuals were accurate to about \pm 5 individuals, less than 200 individuals to about \pm 10 individuals and those greater than $200 \mathrm{~m}$ to \pm 20 individuals. Positions were determined from a Global Positioning System (Garmin etrex) within $300 \mathrm{~m}$ circle of the identified whales. Cetaceans were identified according to Carwardine (2005) and Gill and Gibson (1997).

Arc GIS 10.1 software package was used to geo-position the cetacean sighting and the sea surface temperature, surface salinity and surface density were overlaid by creating into raster or vector maps (Aronoff 1989) as appropriate, to display in a visual format.

Environmental profiles consisting of the mean, median, standard deviation, and range were tabulated for each of the 6 most abundant species or species groups. To test whether species or species groups could be differentiated with regards to temperature, sea surface salinity and sea surface density, one way ANOVA and Tukey's test were carried out after removing outliers (significance defined as $\alpha=$ 0.05). All statistical analysis was carried out using SPSS software (SPSS v 16.0).

\section{Results}

Six species of Sub Order Odontoceti and two species of Sub Order Mysticeti were recorded during the studying period (Table 1). Sightings of killer whale (Orcinus orca) and fin whale (Balaenoptera physalus) were less than ten. Distribution of eight species of cetaceans in the study area is shown in Fugre 2.

Table 1. Recorded cetacean species during the study period.

\begin{tabular}{lll}
\hline Sub Order & Scientific Name & Common Name \\
\hline Odontoceti (toothed whale) & Physeter macrocephalus & Sperm whale \\
& Globicephala melas & Short finned pilot whale \\
& Peponocephala electra & Melon headed whale \\
& Orcinus orca & Killer whale \\
& Tursiops truncates & Bottlenose dolphin \\
& Stenella longirostris & Spinner dolphin \\
Mysticeti (baleen whale) & Balaenoptera musculus & Blue whale \\
& Balaenoptera physalus & Fin whale \\
\hline
\end{tabular}




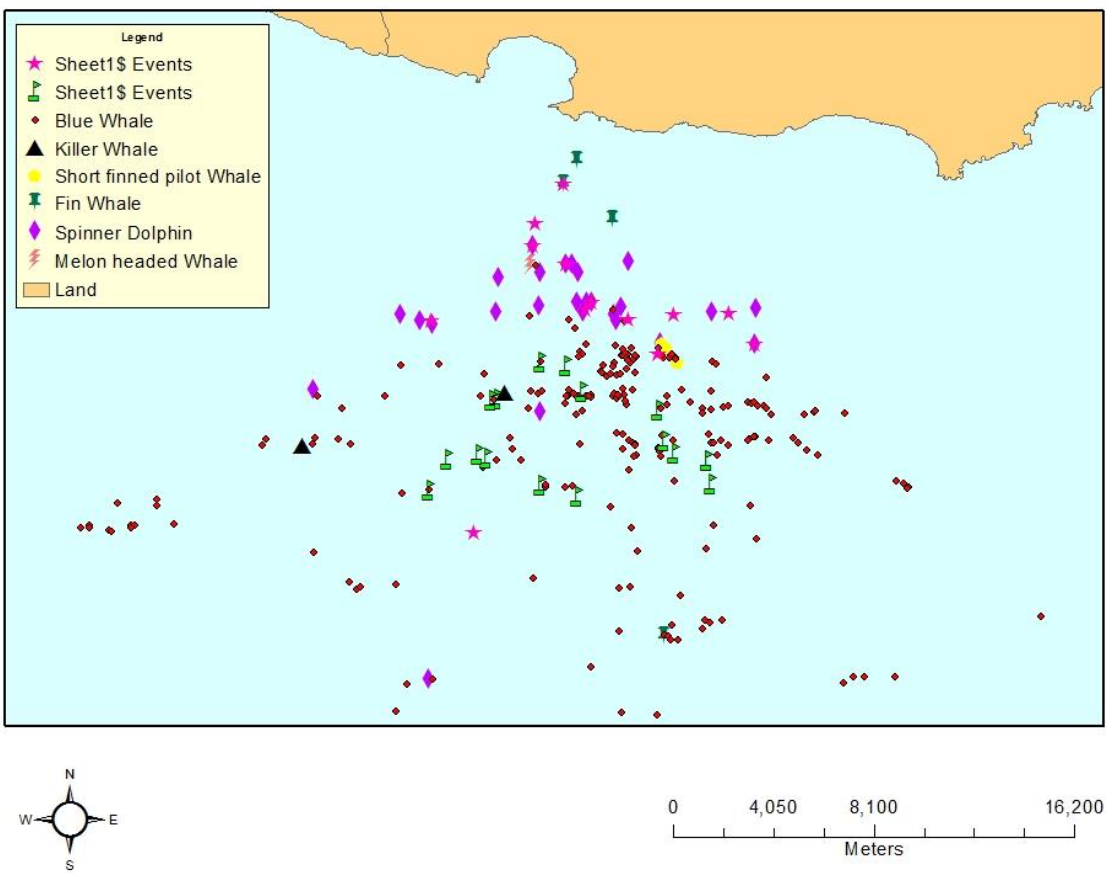

Figure 2. Distribution of eight cetacean species off Mirissa in southern coast of Sri Lanka during the study period.

Spinner dolphins, melon headed whales and bottlenose dolphins were always recorded at relatively to near shore areas (Figure 3). Fin whales, killer whales and short finned pilot whales were sighted relatively somewhat far to the shore line and sperm whales and blue whales were sighted relatively far from the shoreline (Figure 3). There were slight variations of sea surface temperature, sea surface salinity and sea surface density in different cetaceans inhabiting areas (Figure 4). 




Cetacean Type

Figure 3. Mean distance from the shore to the areas where different cetacean species were present. Error bars are \pm SD. 
E.P.D.N. Thilakarathne et al./Sri Lanka J. Aquat. Sci. 20 (1) (2015): 35-45


Figure 4. Variations of (a) sea surface temperature, (b) salinity, and (c) density in the study area. 
There was a significance difference $(\mathrm{p}<0.05)$ among species or species categories with regard to sea surface salinity. However, there were no significant relationships $(p>0.05)$ with sea surface salinity for short-finned pilot whales, bottlenose dolphins and spinner dolphins.

A significant difference $(\mathrm{p}<0.05)$ was found among species or species categories with regard to sea surface density. Nevertheless, there were no such significant relationships ( $p>0.05$ ) for short-finned pilot whales, bottlenose dolphins and spinner dolphins.

Although a significant difference $(\mathrm{p}<0.05)$ was evident among species or species categories with regard to sea surface temperature, there were no significant relationships $(\mathrm{p}>0.05)$ for sperm whale, blue whales and spinner dolphins as well as for melon headed whales, bottlenose dolphins and short-finned pilot whales.

After removing outlier data, box plots for each parameter were obtained for different cetacean species or species categories (Figure 5). The salinity differentiation among cetacean species was not in a broader range, but it was significant. The median salinity level of spinner dolphin and bottlenose dolphin was $35 \mathrm{ppt}$. There was no significant differentiation of the occurrence of them in average salinity level.

Sperm whales, blue whales and melon headed whales were recorded in higher salinity level which was about $36 \mathrm{ppt}$. The recorded median salinity of short finned pilot whale was about 35 ppt. The average sea surface salinity of the study area where all cetacean species were sighted was about 35.2 ppt while median salinity was about 35 ppt. The recorded salinity values were in agreement with those reported by Davis et al. (1998).

The surface density changes of the study area are related to the sea surface salinity. When high salinity change could not be observed, a significant difference among species categories could be seen. The median surface water density where bottlenose dolphin, spinner dolphin and short finned pilot whales inhabited in the study area was about $1.025 \mathrm{~g} \mathrm{~cm}^{-3}$. Nevertheless it was about $1.026 \mathrm{~g} \mathrm{~cm}^{-3}$ for sperm whales, blue whales and melon headed whales.

The average sea surface density of the study area was $1.025 \mathrm{~g} \mathrm{~cm}^{-3}$. Identified cetaceans were recorded in areas with different sea surface temperature. Blue whales and sperm whales were recorded in relatively high temperature areas which ranged between $28^{\circ} \mathrm{C}$ and $28.5^{\circ} \mathrm{C}$. The average sea surface temperature of the areas where spinner dolphins inhabited was recorded to be higher than $28^{\circ} \mathrm{C}$. However, other cetaceans in the family Delphinidae were recorded in relatively low sea surface temperature $\left(27^{\circ} \mathrm{C}-27.5^{\circ} \mathrm{C}\right)$. 
Table 2. Oceanographic data in the study area with 10 or more sightings of cetaceans.

\begin{tabular}{|c|c|c|c|c|c|c|c|c|c|c|}
\hline \multirow{2}{*}{$\begin{array}{l}\text { Species/ } \\
\text { Species } \\
\text { category }\end{array}$} & \multirow{2}{*}{$\begin{array}{l}\text { Number } \\
\text { of } \\
\text { sightings }\end{array}$} & \multicolumn{3}{|c|}{$\begin{array}{l}\text { Surface water } \\
\text { temperature }\left({ }^{\circ} \mathrm{C}\right)\end{array}$} & \multicolumn{3}{|c|}{$\begin{array}{l}\text { Surface water density } \\
\qquad\left(\mathrm{g} \mathrm{cm}^{-3}\right)\end{array}$} & \multicolumn{3}{|c|}{$\begin{array}{l}\text { Surface water salinity } \\
\text { (ppt) }\end{array}$} \\
\hline & & $\begin{array}{l}\text { Mean } \\
\pm \text { SD }\end{array}$ & Range & Median & $\begin{array}{l}\text { Mean } \\
\pm \text { SD }\end{array}$ & Range & Median & $\begin{array}{l}\text { Mean } \\
\pm S D\end{array}$ & Range & Median \\
\hline $\begin{array}{l}\text { Spinner } \\
\text { dolphin }\end{array}$ & 5382 & $\begin{array}{l}35.12 \\
\pm 0.34\end{array}$ & $35-36$ & 35 & $\begin{array}{l}1.025 \\
\pm 0.00\end{array}$ & $1.025-1.026$ & 1.025 & $\begin{array}{l}28.2 \pm \\
1.04\end{array}$ & $27-30$ & 29 \\
\hline $\begin{array}{l}\text { Bottlenose } \\
\text { dolphin }\end{array}$ & 843 & $\begin{array}{l}36.34 \\
\pm 0.75 \\
\end{array}$ & $35-39$ & 36 & $\begin{array}{l}1.026 \\
\pm 0.00 \\
\end{array}$ & $1.025-1.029$ & 1.026 & $\begin{array}{l}28.5 \pm \\
0.90 \\
\end{array}$ & $26-31$ & 28.5 \\
\hline $\begin{array}{l}\text { Sperm } \\
\text { whale }\end{array}$ & 122 & $\begin{array}{l}35.98 \\
\pm 0.66\end{array}$ & $35-37$ & 36 & $\begin{array}{l}1.025 \\
\pm 0.00\end{array}$ & $1.025-1.027$ & 1.026 & $\begin{array}{l}28.5 \pm \\
0.93\end{array}$ & $27-29.5$ & 28 \\
\hline $\begin{array}{l}\text { Short- } \\
\text { finned } \\
\text { pilot whale }\end{array}$ & 24 & $\begin{array}{l}35.25 \\
\pm 0.68\end{array}$ & $35-37$ & 35 & $\begin{array}{l}1.025 \\
\pm 0.00\end{array}$ & $1.025-1.027$ & 1.025 & $\begin{array}{l}27.1 \pm \\
0.17\end{array}$ & $27-27.5$ & 27 \\
\hline $\begin{array}{l}\text { Melon } \\
\text { headed } \\
\text { whale }\end{array}$ & 20 & $\begin{array}{l}35.55 \\
\pm 0.51\end{array}$ & $35-36$ & 36 & $\begin{array}{l}1.025 \\
\pm 0.00\end{array}$ & $1.025-1.026$ & 1.026 & $\begin{array}{l}27.7 \pm \\
0.26\end{array}$ & $27.5-28$ & 27.5 \\
\hline Study area & 6775 & $\begin{array}{l}35.20 \\
\pm 0.48 \\
\end{array}$ & $35-39$ & 35 & $\begin{array}{l}1.025 \\
\pm 0.00\end{array}$ & $1.025-1.029$ & 1.025 & $\begin{array}{l}28.5 \pm \\
1.11\end{array}$ & $26-31$ & 28.6 \\
\hline
\end{tabular}



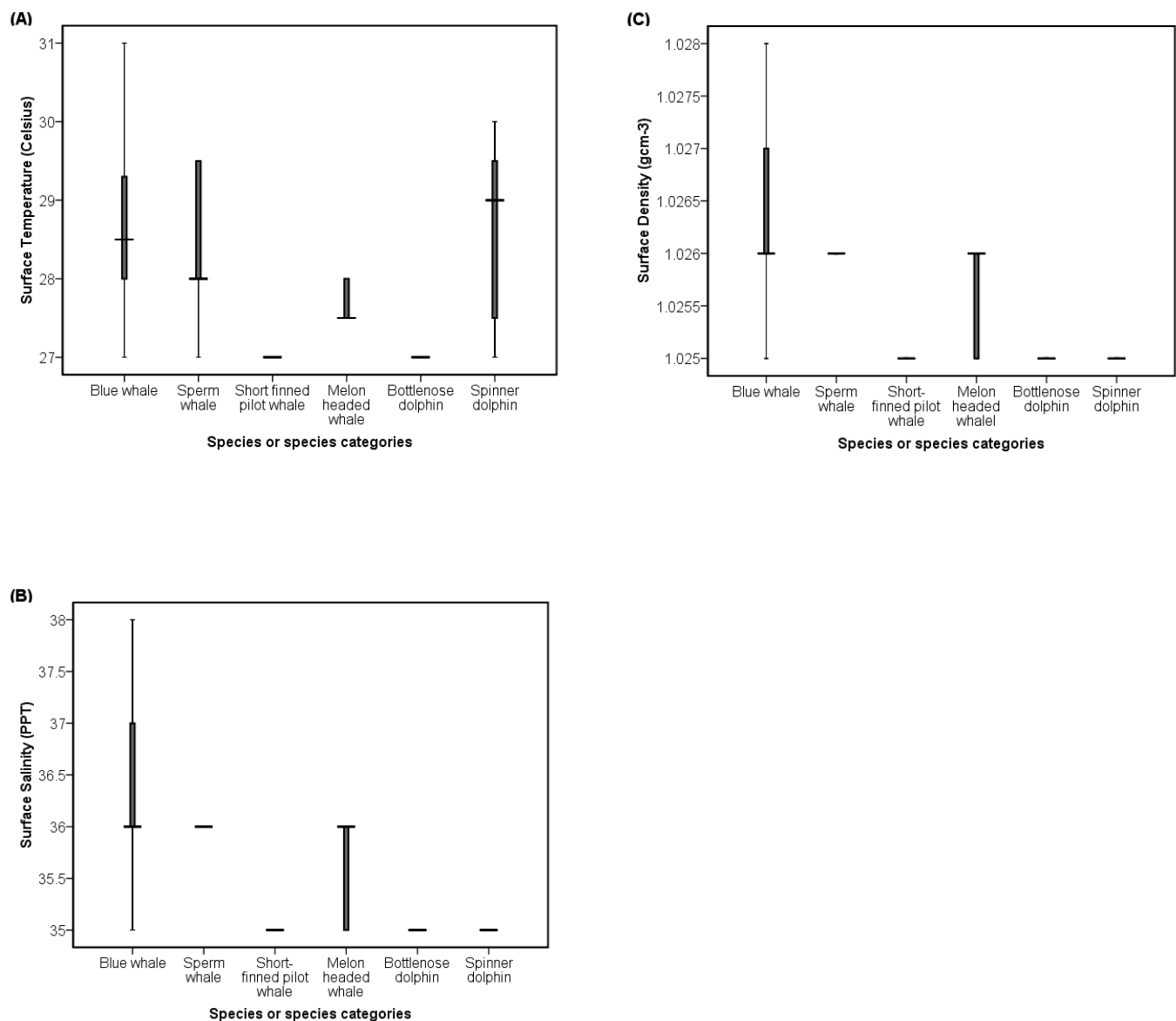

Figure 5. Box plots of (a) sea surface temperature, (b) sea-surface salinity, and (c) sea-surface density associated with the sightings of the 6 cetacean species or species groups. The mid-line is the median, the box encompasses the interquartile range, and the vertical lines are $1.5 \times$ the interquartile range. Outlier points are shown individually as horizontal bars.

\section{Discussion}

Eight cetacean species that have been identified during this study in the southern coast are common species around Sri Lankan water and are 30\% of all species recorded from Sri Lankan waters (Ilangakoon 2002). High abundance and diversity of cetaceans in the southern coastal area might be due to narrow continental shelf and steep continental slope, which are associated with upwelling (Pickart et al. 2009). The year around productivity of the sea is the main reason for the existence 
of the blue whale population in a particular sea area (Vivekanandan and Jeyabaskaran 2012; de Vos et al. 2012). Significant occasions of blue whale sightings were recorded in areas between 4 to 26 nautical miles from the coast. Therefore large numbers of boat trips are organized for tourists especially during the period of north western monsoon (Thilakarathne et al. 2014).

The prominent phytoplankton boom that is correlated with high nutrient level and optimum sea surface temperature of southern coast (Vinayachandran et al. 2004) may be the main reason for the high abundance of cetaceans and specially blue whales throughout the year (de Vos et al 2012). The occurrences of different cetacean species may differ with the environmental condition (Davis et al. 1998), food availability and also with distance from the shore (De Boer 2010). Different sea surface temperature, sea surface salinity and sea surface density were observed during the study area which may influence occurrence of cetaceans. The average temperature of the study area where all cetacean species were sighted was recorded as $28.5^{\circ} \mathrm{C}$ while the median temperature was recorded as $28.6^{\circ} \mathrm{C}$. However, De Boer (2010) reported the sea surface temperature range as low as $20.5^{\circ} \mathrm{C}$ and $27.5^{\circ}$ $\mathrm{C}$ where cetaceans are commonly sighted off Gabon in tropical West Africa. The narrow temperature range that was observed in this study was similar to that reported for pantropical spotted and spinner dolphins in the eastern tropical Pacific seas (Perrin and Hohn 1994).

Mirissa coast is one of the best places to watch blue whales. Currently the whale watching industry turned as a good source of income for coastal community and also empowered the tourism industry of Sri Lanka. The proper management and conservation plan is extremely essential in order to protect and conserve of all cetaceans and also to sustain the whale watching industry.

\section{Acknowledgement}

We are deeply indebted to Mr. R.S. Madushanka for providing the boat and other facilities and to crew of the boat for their support.

\section{References}

Alling, A. K., Dorsey, E. M. \& Gordon, J. C. D. 1991. Blue whales (Balaenoptera musculus) off the Northeast coast of Sri Lanka: distribution, feeding and individual identification. In: Cetaceans and Cetacean Research in the Indian Ocean Sanctuary: Marine Mammal Technical Report 3 (S. Leatherwood and G. P. Donovan (eds), pp. 247-258. United Nations Environment Programme, Oceans and Coastal Areas Programme Activity Centre, Nairobi.

Aronoff, S. 1989. Geographic Information System: A Management Perspective. WDL Publication, Ottawa.

Carwardine, M. 2006. Collins Wild Guide to Whales and Dolphins. Harper Colins, London. 255 p. 
Davis, R.W., G.S. Fargion, N. May, T.D. Leming, M. Baumgartner, W.F. Evans, L.J. Hansen \& K. Mullin 1998. Physical habitat of cetaceans along the continental slope in the north central and western gulf of Mexico. Marine Mammal Science 14(3): 490-530.

De Boer, M.N. 2010. Cetacean distribution and relative abundance in offshore Gabonese waters. Journal of the Marine Biological Association of the United Kingdom 90 (Special Issue 08): 1613-1621.

de Vos, A., T.Wu \& R.L. Brownell, Jr. 2012. Recent Blue Whale Deaths Due to Ship Strikes around Sri Lanka.

https://events.iwc.int/index.php/scientific/SC65a/paper/viewFile/415/385/S C-65a-HIM03 (accessed on $10^{\text {th }}$ Sep 2013)

Gill, P. \& L. Gibson 1997. Whales dolphins and porpoises. Reader's Digest. $1^{\text {st }}$ edition. Reader's Digest Explores series, New York 160 p.

Ilangakoon, A. 2002. Whales and Dolphins, Sri Lanka: a guide to the cetaceans in the waters around Sri Lanka. Wildlife Heritage Trust Publications Ltd., Colombo. 99 p.

Perrin, W.F. \& A.A. Hohn 1994. Pantropical spotted dolphin Stenella attenuata. pp. 71-98. In: Handbook of marine mammals: the first book of dolphins (S.H. Ridgeway and R. Harrison, eds). Academic Press, London.

Pickart, R. S., Moore, G. W. K., Torres, D. J., Fratantoni, P. S., Goldsmith, R. A. \& Yang, J. Y. 2009. Upwelling on the continental slope of the Alaskan Beaufort Sea: Storms, ice, and oceanographic response. Journal of Geophysical Research 114, C00A13, doi:10.1029/2008JC00500.

Thilakarathne, E.P.D.N., P.B.T. Pradeep Kumara \& R.M.G.N. Thilakarathna, 2014. Socio economic aspects of whale watching industry in Southern coast of Sri Lanka. 11th Academic Sessions, University of Ruhuna.

Vinayachandran, P.N., P. Cahuhan, M. Mohan \& S. Nayak 2004. Biological response of the sea around Sri Lanka to summer monsoon. Geophysical Research Letters 31(1), L01302, doi:10.1029/2003GL018533.

Vivekanandan E. \& R. Jeyabaskaran 2012. Marine Mammal Species of India. Central Marine Fisheries Research Institute, Kochi. 228 p. 